\title{
SUBMACHINE GUNS IN THE ARMED FORCES OF THE NATO COUNTRIES
}

Nenad V. Kovačevića , Goran M. Lazićb ${ }^{b}$ Igor Z. Đorđevićc

a University of Defence in Belgrade, Military Academy, Cadets Brigade, Belgrade, Republic of Serbia, e-mail: inz.84kula@gmail.com, ORCID iD: - Ohttp://orcid.org/0000-0002-0840-0063

${ }^{b}$ University of Defence in Belgrade, Military Academy, Department of Army Weapons and Equipment, Belgrade, Republic of Serbia, e-mail: luckysharklg@yahoo.com, ORCID iD: iohttps://orcid.org/0000-0001-9752-3956,

${ }^{c}$ Serbian Armed Forces, Land Forces, 4. Brigade of Land Forces, Vranje, Republic of Serbia, e-mail: igor.dzo.92@gmail.com, ORCID iD: (Dhttps://orcid.org/0000-0002-6497-6083

DOI: 10.5937/vojtehg67-10205; https://doi.org/10.5937/vojtehg67-10205

FIELD: Weapons

ARTICLE TYPE: Professional Paper

ARTICLE LANGUAGE: English

Abstract:

The paper presents a brief review of modern achievements and directions of further development of one type of small arms in the armament of foreign armed forces - namely, submachine guns in the armed forces of the countries signatories of the North Atlantic Treaty Organization (NATO). The article follows the historical genesis of the development of the use of submachine guns as specific types of small arms. Access to recent literature represented a major problem; consequently, data from the Internet was largely used. Submachine guns are one of the most effective and efficient types of infantry weapons of foreign armed forces so a more versatile look at the effects of their use is purposeful as well as the need for innovation and investing in our own resources. The article presents a synthesis of the authors' practical experience with the use of submachine guns and the relevant theoretical knowledge.

Key words: NATO countries, armed forces, submachine guns.

\section{Introduction}

Submachine guns fall into the category of small arms and are intended for action against live targets that are rapidly moving. They are especially effective for fighting at close ranges, especially in combat operations in trenches, forests, mountains, and urban settlements. The 
basic features of submachine guns are simplicity of design and ease of use while the effective range is up to $200 \mathrm{~m}$. (Arsić, 2002a)

Although they were one of the most massively used weapons during the Second World War, submachine guns today have relatively limited use and are used mostly by members of special units in almost all foreign armed forces (airborne units, military police units, and counter-terrorist units). Exceptions are crew members of armored and other combat vehicles and artillery weapons. Neglecting the development of submachine guns compared to other types of small arms is a result of the efforts to develop primarily a unique intermediate cartridge for (semi) automatic rifles due to the logistics needs of armed forces (AF).

Modern submachine guns are made from light metals, plastics, composites and steel. The ammunition capacity of submachine guns ranges from 20 to 100 rounds (usual capacity is from 30 to 35 rounds), and the velocity of the projectile is in the range from 300 to 900 $\mathrm{m} / \mathrm{sec}$. Most often they are equipped with: optical sights, silencers, laser target designators, thermal imaging devices, and most have a folding or retractable stock.

Submachine guns are now mostly based on the $9 \mathrm{~mm}$ Parabellum pistol cartridge, but in recent years designers and manufacturers of weapons have begun to produce submachine guns that use the 5.56x45 $\mathrm{mm}$ and $5.7 \times 28 \mathrm{~mm}$ (NATO standard) or $5.45 \times 39 \mathrm{~mm}$ (GOST) ammunition, with completely new design and constructor solutions as well as in a „bullpup“ configuration. (Mihajlović \& Arsić, 2003)

The greatest attention to developing new models and modifications and to improving the performance of the existing models of submachine guns is paid by American, German and Russian designers of weapons, who emphasize the following advantages of submachine guns over other types of small arms:

$>$ high density of fire,

$>$ rare ricochet bullets,

$>$ high efficiency and effectiveness, and

$>$ high-speed firing.

\section{Basic concepts and classifications of small arms}

Small arms encompass all means intended for destruction and incapacitation of living creatures and moving things by an individual (the shooter). In relation to the source of energy used, these weapons can be divided into: 
$>$ cold weapons, and

$>$ firearms.

Cold weapons use the mechanical energy of the weapon operator or tightened strings. This group of weapons include: daggers, swords, spears, bows and arrows, crossbows, or any other provisional or locally found assets that can be used as a weapon.

Firearms are weapons based on the use of energy of powder gases generated by burning gunpowder. In relation to the purpose of utilization of energy of powder gases created after firing, there are three basic types of firearms:

$>$ non-automatic,

$>$ semiautomatic, and

$>$ automatic. (Generalštab VJ, 1998)

In non-automatic firearms, gunpowder gases energy is only used to provide the initial kinetic energy for a round, or muzzle velocity, while the gun is reloaded and fired manually. The weapons of this type are most often used when greater precision is required, and not high rate of fire as is the case of sniper rifles. (Generalštab VJ, 1998)

In semi-automatic weapons, besides for providing the initial kinetic energy for rounds, the energy of powder gases is used for other automatic operations: extracting and ejecting spent cartridges, cocking the firing mechanism and reloading; however, for each subsequent firing it is necessary to pull the trigger again. (Generalštab VJ, 1998)

In automatic weapons, the propellant gas energy is used to provide the initial kinetic energy to the round, to recharge weapons and fire the next shot as long as the shooter holds the trigger or until there are rounds in the magazine.

According to the purpose and the tactical and technical requirements, weapons of armed soldiers in the land forces of foreign armies can be divided into:

$>$ pistols and revolvers,

$>$ submachine guns,

$>$ rifles,

$>$ rifle-machine guns,

$>$ machine guns,

$>$ automatic guns, and

$>$ automatic grenade launchers. (Arsić, 1996)

Submachine guns are individual weapons designed to destroy live force at close distances. These weapons can achieve high density of fire, because a rate of fire in practice is about 100 rounds/min. Submachine guns are particularly useful in urban areas for combat actions (c/a) where 
the enemy is at close ranges and where larger weapons could not show their full power. Ammunition for submachine guns has been developed based on the pistol round with a small charge, which allowed the production of weapons of simple construction with great firepower. Some submachine guns have fire regulators which enable single fire in addition to the automatic one. Modern submachine guns, unlike the submachine guns used in the Second World War, are lighter and smaller, but still of simple construction.

The principle of operation of most modern submachine guns is based on free bolt recoil (open or closed). Unlike submachine guns of World War II in which the bolt mechanism and other elements were contained behind the barrel, in modern submachine guns bolts are of a telescopic type, that is, bolts are of smaller dimensions and mass, but with still retained other significant characteristics of the weapon. (Petrović, 2009)

The basic, or, in the opinion of most weapon constructors, the most important characteristics of small arms can be divided into four basic groups:

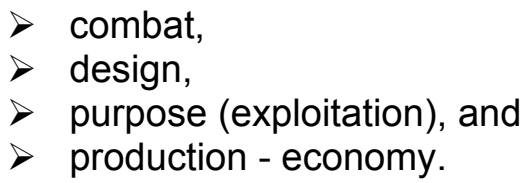

The combat characteristics of weapons consider a possibility of firing at the enemy with normal, i.e. non-failure operation. The combat characteristics of weapons are usually evaluated by three parameters: power of weapons, maneuvering characteristics and reliability of weapon effects. Weapon power is measured by the total amount of energy of fired rounds hitting a target in unit time. The maneuverability of these arms includes their transportability, transfer of fire and the possibility of application under different conditions. The reliability of weapon effects represents the totality of characteristics that show non-failure operation of these weapons, their service life and insensitivity to external influences and damage. (Petrović, 2009)

The design parameters include the following parameters:

$>$ operation flowchart,

$>$ specific constructions of assemblies and parts (type of automation, bolt type, etc.),

$>$ dimensions of weapons in battle and marching positions,

$>$ ease of construction. 
The usage (exploitation) characteristics of weapons should provide simple and uninterrupted operation of all weapon mechanisms as well as firing safety, and also the automatic work and manoeuverability in different conditions of use.

Production-economy characteristics comprise all parameters that provide a simple and inexpensive production of weapons while preserving their quality.

\section{The historical development of the use of submachine guns}

Trench warfare way of c/a, as it was in the First World War, encouraged the construction of unique types of weapons which would later become common on battlefields around the world: hand grenades, sniper rifles, flame throwers, light mortars and submachine guns.

The submachine gun stemmed from an automatic pistol. The first submachine gun was patented by Italian designer of weapons Abiel Revel Botello on 8 April 1914. The first submachine gun had the name of Villar Perosa M15. Botello's invention did not experience success although it had a possibility of firing 1,200 rounds/min. The caliber of this submachine gun was $9 \mathrm{~mm}$; it had two interconnected barrels, each with its own firing mechanism, and an effective range of fire of up to $120 \mathrm{~m}$. The weight was $7,41 \mathrm{~kg}$ and the magazine capacity was 25 or 50 pistol rounds. The weight of the weapon was regarded as its main drawback.

Although not developed on the basis of Botello's invention, the submachine gun of Beretta constructors "Beretta Model 1918“, is also considered one of the pioneering steps in the development of submachine guns as a specific type of small arms. This submachine gun model was developed as a modification of the "Menlicher Corcan“ rifle. It had a wooden stock, an "acceptable“ weight of $3.72 \mathrm{~kg}$, a possibility of firing 900 rounds/min and an $851 \mathrm{~mm}$ long bayonet. The same as Botello's Villar Perosa M15, Beretta's first submachine gun never went into production.

The then Germany was also a pioneer in the development of submachine guns - its military constructors created the first practical construction of a submachine gun, originally called "Maschienpistolen", and then it received the official designation of $9 \mathrm{~mm}$ Bergman MP18/1. During the Battle of Verdun in 1916, Germans realized that the „bolt action rifles" had major limitations in the trench warfare. They were too long, cumbersome to carry, with low rate of fire and too powerful for that type c/a, where target distances rarely exceeded $180 \mathrm{~m}$, so the rifle with 
the theoretical range of over $1800 \mathrm{~m}$ was totally unnecessary. A shortrange weapon, with a possibility of automatic fire and a large magazine capacity was more than necessary so that the development of Bergman became a landmark in the further development of these types of weapons. (Petrović, 2009)

The Bergman MP18/1, shown in Figure 1, was the invention of two German weapon construction giants, Hugo Schmeisser and Theodore Bergman. The MP18/1 or "Musk“, as it was called by German soldiers, resembled Mauser k98 (mostly by the shape of its wooden stock) and had a length of $815 \mathrm{~mm}$ and a weight of $5.26 \mathrm{~kg}$. it was serviced by two soldiers (gunner and his assistant). It used the $9 \mathrm{~mm}$ Parabellum ammunition, had the option of firing 650 rounds/min and a range of effective fire of $70 \mathrm{~m}$, which was ideal in trench warfare.

Between late 1916 and 1918, about 30,000 copies of this submachine gun were produced and it was often copied in other countries. The MP18/1 had several drawbacks, the main one being the use of an unreliable small drum from a Luger pistol which was soon replaced by a simpler box-magazine of the capacity of 32 rounds. The term "submachine" originated from the use of a smaller caliber round than that of a rifle round, i.e. a specific type of a pistol round, and the fact that it was able to achieve full automatic fire. Although it proved to be a very effective weapon, the MP18/1 manufacture did not continue after the First World War because Germany empire was defeated and its arms production was banned by the Versailles Peace Treaty.

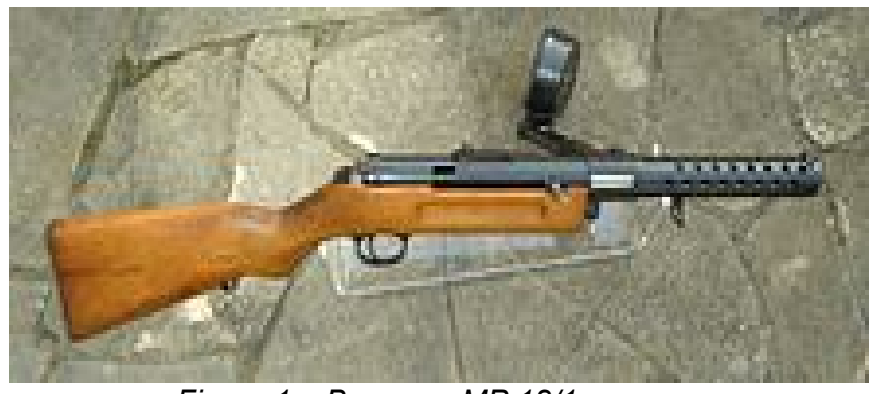

Figure 1 - Bergman MP 18/1

Pис. 1 - Бергман МП 18/1

Слика 1 - Bergman MP 18/1

The Allies were also aware of the need to modify existing weapons to fight in trenches; however, British soldiers as well as their military leadership did not have enough confidence to arm individuals with automatic weapons. Namely, it was believed that a soldier armed with 
automatic weapons would fire all the rounds in a short time, after which he would remain helpless on the battlefield. But the real reason was hidden in the fact that, in times of war, a small number of countries were ready to introduce a greater volume of new technology into the war economy which was already under great strain due to the production of war materials.

The United States of America, which joined the war in 1917, shared the same view and was also reluctant to accept new technologies. The US Rifle, Model M1903 Springfield, was considered the best military rifle, and a good part of American soldiers were armed with the Colt M1911semi-automatic pistols. Nevertheless, reports from battlefields which were coming to the command of US AF began to indicate that the Colt proved to be an excellent weapon to fight in trenches, which was not the case with the Springfield rifle.

Head of the Small Arms Department in the US Army Technical Service Command from 1914 Brigadier General John T. Thompson was of the opinion that, despite economic difficulties, there had to be work on developing new weapons technology. Thanks to General Thompson, there was enormous development of small arms, and in the heart of this development lies the invention of one of the most popular submachine guns ever. With the outbreak of the war, General Thompson left the army and became Head of the Construction Department in the Remington comany. Together with his son, Lieutenant Colonel Marselius Thompson, in 1916 he founded a company for design and production of arms under the name Auto-Ordnance Corporation. (Arsić, 2002b)

General Thompson returned to the army to his old appointment in 1917, when he became responsible for supplying the Army with small arms. He was especially interested in the disadvantages of standard military rifles, bearing in mind the fact that he had already had a vision of the submachine gun project. For developing new weapons, Thompson hired several talented individuals, especially captain John $\mathrm{N}$. Bliss (seaman, mathematician and physicist who had already discovered important properties of certain metals associated with adhesion that were applicable in the construction of locking mechanisms) and constructor Theodore $\mathrm{H}$. Ejkof (soon to become a senior engineer in the newly opened Auto-Ordnance Company). Ejkof had extensive experience in the construction of weapons since he had worked in technical service before the war, where at one time he was engaged on a study of the existing automatic weapons being developed worldwide.

The prototype of the first Thompson submachine gun „saw the light of the day" in September 1917 and was called "Thompson Auto 
Rifle". This submachine gun was a basic version of all models of Thompson submachine guns that would appear several years later. The prototype itself had a lot of shortcomings, notably in terms of locking the barrel, so the Thompson submachine gun was not to enter into operation in the US Armed Forces during the First World War, but during the forties of the 20th century. It is interesting that this weapon was first accepted by criminals from Chicago and New York City during the Prohibition era. Police and the Bureau of Investigation, who considered themselves poorly armed, armed their forces with Thompson submachine guns, especially with a special model M1921A shown in Figure 2. This submachine gun model got a lot of publicity in clashes of the police with gangsters, especially after its use in the massacre on St. Valentine's Day 1929. It soon attracted the attention of Hollywood producers and started to be used a lot in films. In fact, Thompson's appearance in the movies was not in proportion to its use on the streets and under the normal circumstances it would have surely faded in the late thirties because the police had already dealt successfully with gangs by that time. (http://world.guns.ru/smg-e.html)

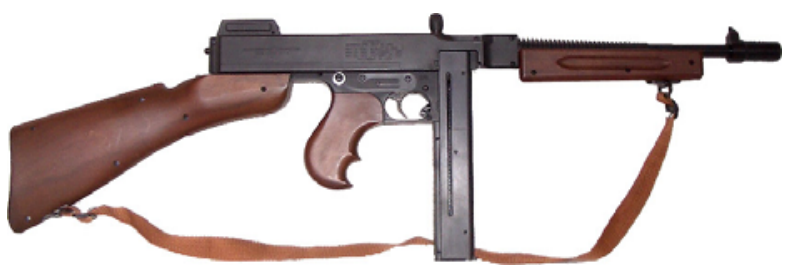

Figure 2-M1921 Submachine gun

Puc. 2 - Автомат M1921

Слика 2 - Аутомат M1921

The Japanese attack on Pearl Harbor in December 1941 made the US forces quickly arm themselves in order to fight in the war. The US AF then had more or less identical weapons that had been used in the First World War. Despite the fact that the concept of submachine guns was never particularly attractive in the US AF, and that the Thompson was not widely accepted for use in military units, it was available in the market. It became an obvious choice for land forces and Marine Corps, and later the Thompson, affectionately nicknamed „Tommy Gun" became world known and accepted as the most famous Allied submachine gun of the Second World War.

The Auto-Ordnance Company soon realized the importance of that nickname and patented it. The Thompson was used by Americans, 
British, French, Indians, Australians, Canadians, South Africans, New Zealanders, Soviets, Chinese, Yugoslavs, etc. It was used in combat in all types of terrains - in deserts, mountains, jungles and forests, in the fields and in the streets - and in all environments it proved to be highly effective and usable. No one called it perfect, because the fact is that it was not - but one thing is certain: no one relinquished its services. Firepower generated by $11.43 \mathrm{~mm}$ rounds was always welcome in all combat situations. Few of those who received a rafal from the Thompson survived to testify about its combat power. The production of the Thompson submachine gun finally stopped in 1944, after 1,387,134 produced pieces. (http://world.guns.ru/smg-e.html)

In preparation for conducting „blitzkrieg“ (a rapid war), Germany's weapons introduced a whole range of new models of small arms. One of the most interesting models is certainly the MP38 submachine gun (Figure 3) - the most famous military submachine gun of all times. It was often called Schmeisser, although constructor Hugo Schmeisser had nothing to do with its design or production (constructor was Volmer and it was produced in the "Erma-Werke" company). It was a synonym of German firepower and the „blitzkrieg“ doctrine in general. The Germans used it in their marketing campaigns, on propaganda posters. Its enormous fame was largely accredited to the Hollywood industry in the postwar years due to which there was an impression that every second member of the Wehrmacht was armed with the Schmeisser submachine gun.

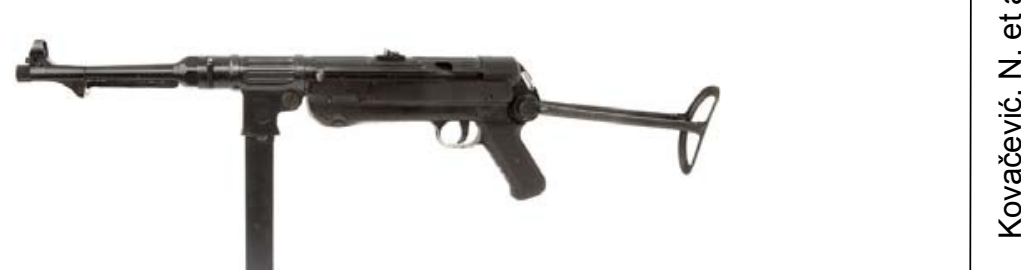

Figure 3-MP 38 Submachine gun

Puc. 3 - Автомат МП38

Слика 3 - Аутомат MP38

This was far from the reality. Schmeissers were relatively rare in the armament of the Wehrmacht. In the period from 1939 to 1945, there were a total of 908,317 pieces produced, which is almost negligible compared to the multimillion production of K98k carbines. On the battlefield, a submachine gun was inferior to the K98k, particularly in relation to MG34, MG42 and StG44 machine guns. True, it was designed as a tank crew weapon, for paratroopers and close combats in urban areas, i.e. primarily 
for special troops, and not for the overall use. Finally, during its exploitation, several dangerous defects came to light. (http://militarytoday.com)

In the early days of the war, the production of the MP38 showed to be quite expensive, and it was necessary to have cheaper, faster and more massive production of weapons. The technology of metal stamping began to be used in the production of small arms. The production of the MP38 with the application of new technologies started between March and July 1940. This new model, the MP40 submachine gun, was basically the same weapon, but with differences in the receiver and bolt as well as the magazine housing. Therefore, the main difference was in the production, because this model used stamped sheet metal and simple component parts which could be produced by other manufacturers throughout Germany. The use of high-quality steel was avoided to the greatest extent, and spot welding was used for binding parts. Mass production of MP40s was entrusted to the firms: „Erma“, „Haenel“, and „Steyr". (Petrović, 2009)

The MP40 had several varieties, but the appearance was little altered. The most interesting version was the MP40 / II. The new model was produced in late 1943 and had a double housing stock which could accommodate two magazines with 32 rounds each. One was connected to the feed mechanism and when it ran out, the other was repressed in its place, i.e. inserted. This model was actually an attempt of German constructors to respond to the Soviet submachine gun, the PPs model. In practice, this did not work well because of the heavy weight and poor balance. A weapon with a wooden stock, based on the MP40, known under the name of the MP41, was Haener's trial investment, but never accepted as an official weapon.

During combat exploitation, soldiers noticed a few drawbacks of this submachine gun. First, delays occurred after the first shot was fired. Germans long studied the reasons for these deadly flaws. Several causes were found: soldiers would hold the magazine instead the foregrip, which, during recoil, led to its malfunctioning and change in the feed angle. Soldiers were instructed to lubricate the magazine, dirt would mix with lubricating oil and the friction between the magazine walls and cartridges would increase from a coefficient of 0.15 to 0.30 . In addition, a zigzag arrangement led to an unfavorable pressure between the ammunition and rounds changing their positions. This flaw was never completely eliminated, although strict instructions about holding the weapon were issued, a stronger feed spring was introduced (which 
decreased the ammunition capacity from 32 to 28 rounds) as well as a new regulation on cleaning and maintenance. (Petrović, 2009)

The second flaw was accidental firing when the bolt was in the forward position. Due to large recoil forces and inertia, the bolt would "fly" backwards and perform charging and firing. As a temporary solution, an instruction was issued to apply a special leather harness fixed around the barrel. The bolt handle was firmly fixed with a special loop. This temporary solution was even commended, because the harness was covering the cartridge ejection port and prevented penetration of dirt. As a permanent solution, from the mid-1942, all manufactured submachine guns had the old cocking handle replaced by a new one, the head of which would be secured in the forward position by being pushed into the notch on the magazine. Replacement was completed by mid-1943 (adapted M38s were labeled as MP38/40s), and all newly produced submachine guns were fitted with new handles. (Petrović, 2009)

The end of the Second World War saw a huge surpluses of various low-cost submachine guns left behind, and the development of small arms, mainly semi-automatic rifles in bigger calibers, went in a different direction. The development of new, fully automatic assault rifles in smaller rifle calibers, gave another dimension and much more firepower to infantry weapons than they previously used to have. In the West, the development of assault rifles began around the $7.62 \times 51 \mathrm{~mm}$ NATO cartridge, and soon went on to small-caliber ammunition by introducing the American M-193 5.56x45 mm cartridge as the NATO standard. The development of a new concept of weapons and the new generation of assault rifles (initially started by German constructors during the war), especially their shorter and lighter versions at the end of the sixties of the 20th century, made the submachine gun lose its importance as a basic combat weapon because of its limitations in range, accuracy and firepower. From the military point of view of the great powers, it was thought to have lost any significance. (Vojvodić, 2009, pp.11-12)

Thus, in the late sixties and early seventies, production of submachine guns ceased almost completely because they were considered to be completely anachronistic and acceptable only as an auxiliary weapon to equip non-combat units. Limited use of submachine guns remained important only in Third World countries which mainly did not have their own production of modern assault rifles. A milestone for further development, or actually for the survival of submachine guns, lies in the formation of a new German weapons factory - Heckler \& Koch. The founders, but also the leading tandem of constructors, were Edmond Heckler (1906-1960) and Theodore Koch (1905 -1976). In a very short 
time, in 1956, their new model of an assault rifle, the G3, appeared for the purpose of arming the Bundeswehr. It was developed in the then dominant Western (American) $7.62 \times 51 \mathrm{~mm}$ NATO and .308 Winchester caliber. Their solution, which combined an ingenious locking system solution (delayed recoil) with movable rollers, taken from the MG-42 machine gun and the then new and revolutionary technology of making weapons using pressed sheet metal and components from molded plastic, resulted in a new and very unusual assault rifle, the G3, which has become one of the leading and most respected western infantry weapons in the world. (Vojvodić, 2009, pp.11-12)

Experimenting with different variants of rifles soon resulted in some compact models designed for some more modern and weaker ammunition (5.56x45 M193 first, then Soviet 7.62×39 M43 ammunition and $5.45 \times 39$ for small arms). During 1964, a maximally reduced, facilitated and redesigned version appeared, intended for pistol ammunition, primarily for the $9 \mathrm{~mm}$ Para, as well as for a more archaic Soviet 7.62x25 TT. This last variant was called the MP5 (Maschinenpistolen model 5-slot model 5). In 1996, the MP5 in 9x19 Parabellum caliber was introduced in serial production at the request of the German border police who needed such weapons to equip their members.

The new MP5, Figure 4, kept the locking mechanism from the assault rifle from which it originated so the bolt was closed and locked during operation thus proving to be much more precise than all previous submachine guns. In addition, built to the highest technological standards of the time (almost unattainable today), it was the first weapon in the world with absolute possibility of replacement of all parts of all produced copies ever. Experiments of this type were carried out in our country, in the Institute of Security in Belgrade after purchasing this model; all parts of ten submachine guns were disassembled and mixed to be later assembled randomly, and SMGs continued to function flawlessly. After the terrorist attack on the Israeli Olympic delegation in Munich in 1972, the German border police (Bundesgrenzschutz) formed a first special unit in this country, called GSG-9 (Grenzschutzgrupe 9), which immediately included this already proven submachine gun in their standard arsenal. So this weapon, along with the prestige of this unit, slowly began to appear in the armaments of those who looked up to it. (Vojvodić, 2009, pp.11-12)

The H\&K MP5 tactical - technical characteristics:

$>$ caliber: $9 \times 19 \mathrm{~mm}$,

$>$ weight: $2.28 \mathrm{~kg}$, 
$>$ length: $660 \mathrm{~mm}$,

$>$ barrel length: $225 \mathrm{~mm}$,

$>$ principle of operation: semi-free bolt recoil - closed bolt

$>$ muzzle velocity: $400 \mathrm{~m} / \mathrm{s}$,

$>$ rate of fire: 800 rounds $/ \mathrm{min}$,

$>$ magazine capacity: 15 or 30 rounds,

$>$ effective firing range: $200 \mathrm{~m}$.

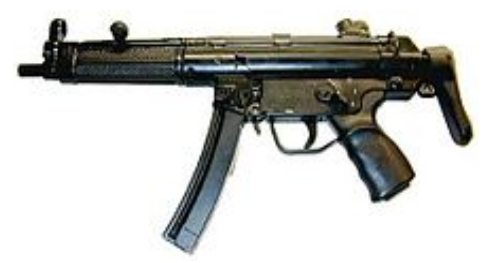

Figure 4-H\&K MP 5 Submachine gun

Puc. 4 - Автомат $X \& K$ МП5

Слика 4 - Аутомат H\&K MP 5

\section{Submachine guns in the use of the armed forces of the NATO countries}

This part of the paper provides an overview of the most popular and the most widely used submachine guns in the armies of the NATO countries. Each submachine gun type (representative of its kind, that is, a particular model) has been described according to its origin, i.e. according to the manufacturer's country, AFs of the NATO countries where it is used (indicating also other security forces using them) and the summary of the basic tactical technical characteristics of each model of submachine guns. Submachine guns of some countries that are not NATO members (Sweden, Israel and Switzerland) are also presented since they are widely used in the armies of the NATO countries (and many others around the world). Due to the lack of recent literature in this field, some of the data was downloaded from the Internet.

The FN P90 submachine gun, shown in Figure 5, was designed and manufactured by the Belgian company FN Herstal. It was created in response to NATO's request for a replacement weapon using $9 \times 19 \mathrm{~mm}$ ammunition. The FN P90 submachine gun was designed as a compact, yet powerful weapon for the crew of combat and other armored fighting vehicles, special units, and counter-terrorist units. It appeared in the early nineties of the 20th century. There are several innovations in the design of the FN P90 such as an integrated reflex sight, a frame, a unique top- 
mounted magazine as well as a special $\mathrm{FN} 5.7 \times 28 \mathrm{~mm}$ pistol ammunition.

Submachine gun feeding is done in a unique way. The magazine is placed on top of the submachine gun receiver, and ammunition is arrayed at an angle of $90^{\circ}$ relative to the barrel. At the end of the magazine, there is a spiral feed ramp that rotates the ammunition coming to it under the action of the spring in the magazine in the direction of the barrel, and alignes it downwards, and, while going to the forward position, the bolt takes a cartridge and places it into the barrel chamber. Also, the receiver is made of semi translucent polymer that allows the shooter to see how much ammunition is left in the magazine. The FN P90 submachine gun operates on the principle of free recoil bolt with the closed bolt. It is suitable for being carried concealed because of its smooth edges. It was made in "bullpup“ design, which means that the magazine and all actions related to firing happen in the stock, thus making it easy to carry and maneuver easily in small and narrow spaces. (Arsić, 1996)

The tactical - technical characteristics:

$>$ caliber: $5.7 \times 28 \mathrm{~mm}$,

$>$ weight: $2.54 \mathrm{~kg}$,

$>$ length: $500 \mathrm{~mm}$,

$>$ barrel length: $263 \mathrm{~mm}$,

$>$ principle of operation: free bolt recoil - closed bolt

$>$ muzzle velocity: $850 \mathrm{~m} / \mathrm{s}$,

$>$ rate of fire: 900 rounds $/ \mathrm{min}$,

$>$ magazine capacity: 50 rounds,

$>$ effective firing range: $200 \mathrm{~m}$.

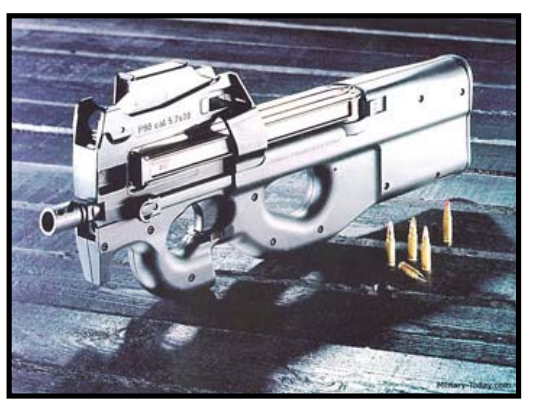

Figure 5 - FN P90 Submachine gun

Puc. 5 - Автомат ФН 790

Слика 5 - Аутомат FN P90 
The Specter M4 submachine gun shown in Figure 6 was developed in Italy by two famous constructors Roberto Teppa and Claudio Gritti in the mid-eighties of the 20th century. This weapon is mostly used in Italy and Switzerland mainly by law enforcement forces. The special characteristic of this submachine gun is the trigger mechanism that works on the principle of double action. The bolt handle is located on top so cocking can be done with both hands. The ammunition is fed by the magazine of the capacity of 30 and 50 rounds. It is worth noticing that the civilian version is available with 5,10 and 15 -round magazines. The main drawback of this submachine gun is a small range of effective fire. (http://www.military-today.com)

The tactical - technical characteristics:

$>$ caliber: $9 \times 19 \mathrm{~mm}$ Parabellum,

$>$ weight: $2.90 \mathrm{~kg}$,

$>$ length: $580 \mathrm{~mm}$,

$>$ barrel length: $130 \mathrm{~mm}$,

$>$ principle of operation: free bolt recoil - closed bolt

$>$ muzzle velocity: $400 \mathrm{~m} / \mathrm{s}$,

$>$ rate of fire: 850 rounds/min,

$>$ magazine capacity: 30 and 50 rounds,

$>$ effective firing range: $50 \mathrm{~m}$.

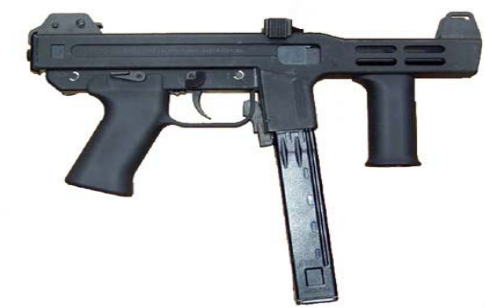

Figure 6 - Spectre M4 Submachine gun

Puc. 6 - Автомат Spectre M4

Слика 6-Ayтомат Spectre M4

The Steyr TMP submachine gun, shown in Figure 7, was designed in the famous Austrian military company Steyr-Mannlicher in the early nineties of the 20th century. Its production officially began in 1992 and terminated in 2001 primarily due to poor sales. The license for the production was transferred to a Swiss company and one of the design solutions is still produced. The Steyr TMP submachine gun enables slower, but more controlled fire. It has been found that it is very stable during automatic fire. The shooter fires a burst of 10 to 15 rounds while other submachine guns are limited to a burst of 2 to 3 rounds. Many parts 
of the submachine gun are made of polymer. It is interesting that there is no stock, and that it can be fired single-handedly. It has 15 and 30-round magazines.

The tactical - technical characteristics:

$>$ caliber: $9 \times 19 \mathrm{~mm}$,

weight: $1.30 \mathrm{~kg}$,

$>$ length: $282 \mathrm{~mm}$,

$>$ barrel length: $130 \mathrm{~mm}$,

$>$ principle of operation: free bolt recoil - closed bolt

$>$ muzzle velocity: $370 \mathrm{~m} / \mathrm{s}$,

$>$ rate of fire: $800-900$ rounds $/ \mathrm{min}$,

$>$ magazine capacity: 15 and 30 rounds,

$>$ effective firing range: at 50 to $100 \mathrm{~m}$.

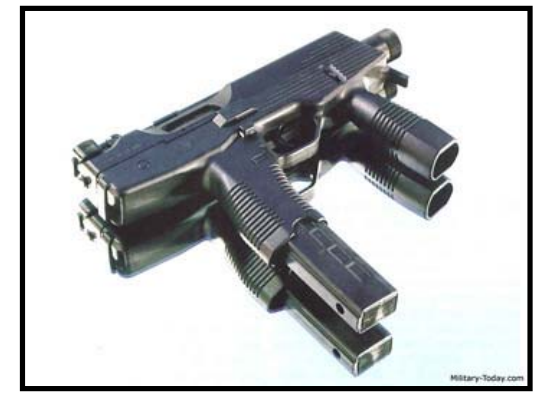

Figure 7 - Steyr TMP Submachine gun

Puc. 7 - Автомат Steyr TMП

Слика 7 - Aутомат Steyr TMP

The original Steyr AUG submachine gun, shown in Figure 8, is a modified and improved design of the original Steyr AUG assault rifle. It is designed for close combat in police and military actions. This weapon combines relatively compact dimensions with good precision, thanks to a long barrel and a closed bolt. If necessary, the Steyr AUG can be fitted with a silencer. Some basic components are taken from the Steyr AUG assault rifle, such as the polymer stock, while the principle of operation is different. What was kept is the hammer-firing mechanism with a special progressive trigger (pulling the trigger halfway produces a single shot while pulling it until the end produces burst fire). Also, the magazine housing has a special magazine adapter. (Mihajlović \& Arsić, 2003)

The tactical - technical characteristics:

$>$ caliber: $9 \times 19 \mathrm{~mm}$ Parabellum,

$>$ weight: $3.50 \mathrm{~kg}$, 
$>$ length: $665 \mathrm{~mm}$,

$>$ barrel length: $420 \mathrm{~mm}$,

$>$ principle of operation: free bolt recoil - open bolt

$>$ muzzle velocity: $400 \mathrm{~m} / \mathrm{s}$,

$>$ rate of fire: 670 rounds $/ \mathrm{min}$,

$>$ magazine capacity: 25 rounds,

$>$ effective firing range: $200 \mathrm{~m}$.

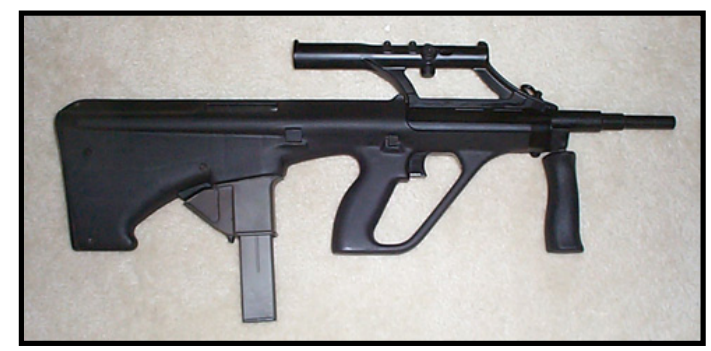

Figure 8 - Steyr AUG Submachine gun

Puc. 8-Aвтомат Steyr AУГ

Слика 8 - Аутомат Steyr AUG

The Brugger \& Thomet MP9 submachine gun, Figure 9, is a modified version of the Steyr TMP. Swiss weapons designers made a total of 19 changes to the TMP. The MP9 submachine gun is currently used in Switzerland, India and Portugal. This submachine gun is smaller than the H\&K MP5, which makes it ideal for special units and law inforcement forces. Its compact size has, however, led to the reduced range of effective fire. The MP9 is designed so that it has an integrated front handle, so it can be easily controlled during automatic fire. This submachine gun can be fired single-handedly. The main novelty of the MP9 compared to the TMP is a side-folding stock and a Picatinny-type scope rail which can accept a wide variety of optical sights. The MP9 submachine gun also has a mechanical sight and is compatible with silencers.

The tactical - technical characteristics:

$>$ caliber: $9 \times 19 \mathrm{~mm}$,

$>$ weight: $1.40 \mathrm{~kg}$,

$>$ length: $523 \mathrm{~mm}$,

> barrel length: $130 \mathrm{~mm}$,

$>$ principle of operation: free bolt recoil - closed bolt

$>$ muzzle velocity: $400 \mathrm{~m} / \mathrm{s}$,

$>$ rate of fire: 900 rounds/min,

> magazine capacity: $15,20,25$ and 30 rounds, 
effective firing range: from 50 to $100 \mathrm{~m}$. (Mihajlović \& Arsić, 2003)

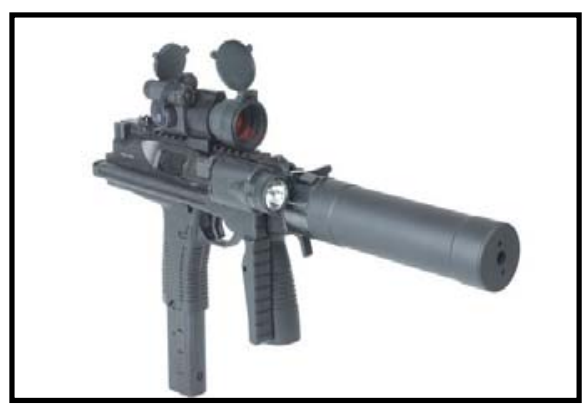

Figure 9-Brugger \& Thomet MP9 Submachine gun

Puc. 9 - Aвтомат Brugger \& Thomet MP9

Слика 9 - Аутомаm Brugger \& Thomet MP9

The Scorpion EVO III submachine gun, Figure 10, is the latest product of the well-known Czech Republic Zbrojovka factory (CZ-UB). Its development began in Slovakia in early 2002 as a submachine gun under the name of Laugo. When the design became famous, it was sold to CZ-UB which in 2009 produced the version Scorpion EVO III. Although this weapon was primarily designed for police forces, it can also be found in some military units. It uses a 9x19 mm Parabellum ammunition, but it is also developed to use .40 S\&W ammunition in order to be sold in foreign markets (primarily the US). It has a separate hammer mechanism and the settings for single shots, 3-round bursts and continuous fire. The bolt handle is on the left side of the weapon. The receiver, the adjustable folding stock, the grip, the trigger mechanism, and the foregrip are made of polymer. Iron sights are mounted on a Picatinny-type scope rail at the top of the receiver, to which various optical sights can be mounted. Additional three Picatinny rails are installed at the level of the foregrip. The magazine is made of transparent plastic.

The tactical - technical characteristics:

$>$ caliber: $9 \times 19 \mathrm{~mm}, .40 \mathrm{~S} \& \mathrm{~W}$

$>$ weight: $2.77 \mathrm{~kg}$,

$>$ length: $660 \mathrm{~mm}$,

$>$ barrel length: $196 \mathrm{~mm}$,

$>$ principle of operation: free bolt recoil - closed bolt

$>$ muzzle velocity: $370 \mathrm{~m} / \mathrm{s}$,

$>$ rate of fire: 1100 rounds/min,

> magazine capacity: 20 and 30 rounds, 
effective firing range: to $200 \mathrm{~m}$. (http://world.guns.ru/smge.html)

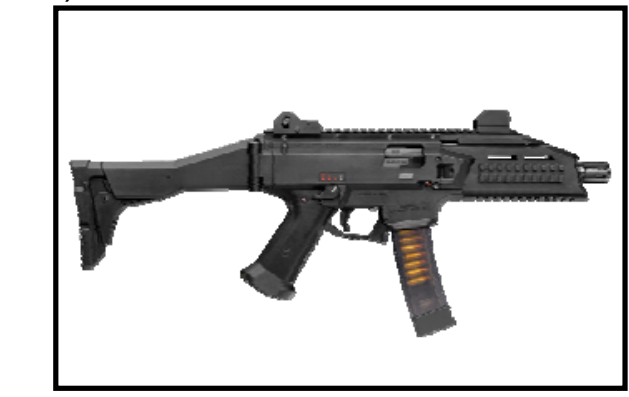

Figure 10 - Scorpion EVO III Submachine gun

Puc. 10 - Aвтомam Scorpion EBO 3

Слика 10 - Аутомат Scorpion EVO III

The Kriss Super V submachine gun, Figure 11, was designed by TDI company. Its name comes from the name for the Indonesian sword or large knife. It works on the principle of free bolt recoil and fires from the closed bolt. Its ammunition is .45 ACP $(11.43 \times 23 \mathrm{~mm})$. A version for caliber .40 S \& \# 38; W (10x22 mm Smith \& Wesson) is also available. Due to a special system, the Kriss Super $V$ has reduced recoil and muzzle climb. The recoil force is redirected downwards, which improves overall weapon control. The producer claims that this submachine gun has $60 \%$ less recoil and $95 \%$ less muzzle climb. It is fed from the standard Glock 21 magazine with 13 rounds, optionally 30 rounds. The magazine is located in the housing in front of the grip. This weapon has a Picatinny-type rail on top so it can be fitted with iron sights and a variety of sighting devices. This submachine gun has a folding stock and an additional rail below the barrel which is compatible with laser pointers, additional foregrips, flashlights, etc. (http://world.guns.ru/smg-e.html)

The tactical - technical characteristics:

$>$ caliber: .45ACP, .40S\&W

$>$ weight: $2.70 \mathrm{~kg}$,

$>$ length: $620 \mathrm{~mm}$,

$>$ barrel length: $140 \mathrm{~mm}$,

$>$ principle of operation: free recoil of the bolt - closed bolt

$>$ muzzle velocity: $400 \mathrm{~m} / \mathrm{s}$,

$>$ rate of fire: $800-1100$ rounds/min,

$>$ magazine capacity: 13 and 30 rounds,

$>$ effective firing range: $100 \mathrm{~m}$ 


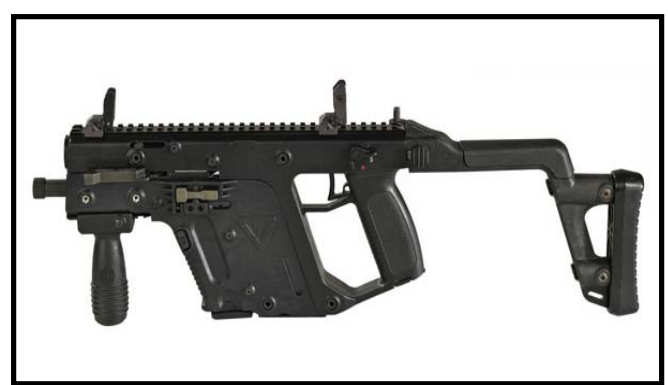

Figure 11 - Kriss Super V Submachine gun Puc. 11 - Автомат Kriss Super V Слика 11 - Аутомат Kriss Super V

The Ruger MP9 submachine gun, shown in Figure 12, is very similar to the Israeli IMI UZI. Designed as a compact weapon for law enforcement forces, this submachine gun was first introduced in early 1995. It was tested by the special units of the British AF - SAS. However, this weapon was produced in limited series. It works on the principle of free bolt recoil and fires from a closed bolt. Some parts of the weapon are made of polymer, primarily to reduce weight. The magazine housing is located in the grip and has a capacity of 32 rounds (the UZI has the same magazines). The Ruger MP9 has a redesigned folding stock. It can be cocked using either hand since the cocking handle is located on top of the weapon. The weapon does not have a Picatinny rail, and uses only mechanical sights.

The tactical - technical characteristics:

$>$ caliber: $9 \times 19 \mathrm{~mm}$ Parabellum,

$>$ weight: $1.83 \mathrm{~kg}$,

$>$ length: $556 \mathrm{~mm}$,

$>$ barrel length: $173 \mathrm{~mm}$,

$>$ principle of operation: free bolt recoil - closed bolt

$>$ muzzle velocity: $370 \mathrm{~m} / \mathrm{s}$,

$>$ rate of fire: $850-900$ rounds $/ \mathrm{min}$,

$>$ magazine capacity: 32 rounds,

$>$ effective firing range: $75 \mathrm{~m}$. (http://military-today.com) 


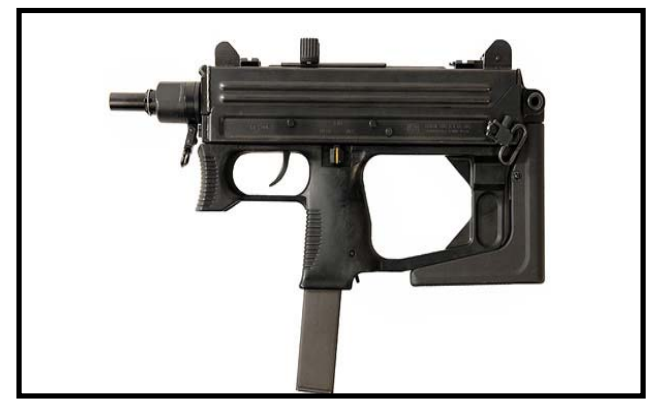

Figure 12 - Ruger MP9 Submachine gun

Puc. 12 - Автомam Ruger MP9

Слика 12 - Аутомат Ruger MP9

The UZI submachine gun, Figure 13, was designed by Israeli designer, Uzziah Gal in 1949, then lieutenant of the just formed AF of the Republic of Israel. The weapon is named in his honor. It was officially adopted in 1951, but become operational in 1954 and was first given to the special units of the Israeli AF. Produced by the IMI company, the UZI was so successful that it was adopted by more than 90 countries around the world, either for the army or the police forces, but it is also a favorite weapon of terrorists around the world. Over the decades, there have been a lot of "family members“ (design versions) of this model. It was licensed and produced in Belgium (FN Uzi) and Rhodesia (Zimbabwe), while the most popular unlicensed variants were produced in China (Model 320) and Croatia (Model ERO). It works on the principle of free bolt recoil and uses an open bolt. The impact of the design of the Czechoslovak submachine gun model SaVz 23 is visible, especially in the magazine housed in the grip. The UZI is simple in design and technology, has relatively few moving parts and is primarily made of metal. The weapon was selected by the Israeli AF primarily due to its simplicity and ease of production. (http://military-today.com)

The magazine is in the grip, which makes it smaller and easier for charging. It is fed by 25, 32, 40 and 50-round magazines. The main shortcomings of the UZI submachine guns are limited range of effective fire and inaccuracy. There are three basic variants: Mini UZI, Micro UZI and UZI Pro. The UZI Pro submachine gun was officially launched in 2003 and represents an improved version of the Micro UZI. It was created based on extensive research by Israeli engineers who conducted the survey and collected the impressions, observations and reports of direct users of the Micro UZI. The UZI Pro is lighter because it uses polymer and titanium alloys. This submachine gun is fed from Glock's 
magazines with a capacity of 17 and 33 rounds. (http://militarytoday.com)

The tactical - technical characteristics:

$>$ caliber: $9 \times 19 \mathrm{~mm}$,

$>$ weight: $3.50 \mathrm{~kg}$,

$>$ length: $650 \mathrm{~mm}$,

$>$ barrel length: $260 \mathrm{~mm}$,

$>$ principle of operation: free bolt recoil - open bolt

$>$ muzzle velocity: $400 \mathrm{~m} / \mathrm{s}$,

$>$ rate of fire: $850-900$ rounds $/ \mathrm{min}$,

$>$ magazine capacity: $25,32,40$ and 50 rounds,

$>$ effective firing range: $200 \mathrm{~m}$.

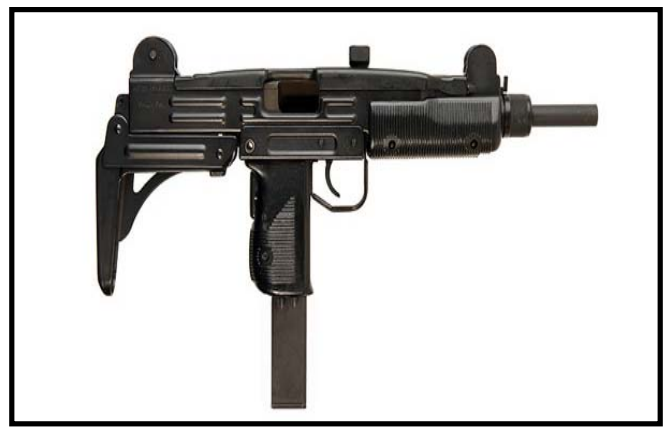

Figure 13 - UZI Submachine gun

Puc. 13 - Автомат UZI

Слика 13 - Аутомат UZI

The CBJ MS submachine gun, Figure 14, was designed by Swedish designer of weapons Bert Johnson who founded a private company for production of weapons, CNJ Tech AB. This submachine gun, i.e. its different design solutions, was presented in the period from 2000 to 2003. This compact weapon is intended for commanders, drivers, tank and artillery crews, pilots and medical staff. The CBJ MS submachine gun works on the gas principle. It fires from a closed bolt. The weapon is actually a modified version of the Israeli UZI. It uses the $6.5 \times 25 \mathrm{~mm}$ ammunition which, during experiments, showed better performance than the 5.56 and $7.62 \mathrm{~mm}$ NATO ammunition. The primary ammunition type of this SMG is an armour-piercing round with greater penetration performance. During trials, the CBJ MS round penetrated the standard Crisat armor at a distance of $230 \mathrm{~m}$. Some weapon designers claim that the CBJ MS is superior to the Belgian FN P90 and the HK MP7. This submachine gun is ideal for close combat and self-defense while being 
also effective against lightly armored vehicles. (http://world.guns.ru/smge.html)

The barrel of the submachine gun can be easily removed for maintenance and/or replacement. The magazine is provided in the handgrip, and has a capacity of 20 or 30 rounds. A spare magazine can be kept in the foregrip to be easily changed. There is also a drum magazine version with a capacity of 100 rounds. This submachine gun has a Picatinny rail which can hold various sights, flashights, laser target designators, and the like. The CBJ MS is now being designed in a few versions and it is obvious that this SMG represents the future, or a tendency of the further development of submachine guns.

The tactical - technical characteristics:

$>$ caliber: $6.50 \times 25 \mathrm{~mm}$,

$>$ weight: $2.80 \mathrm{~kg}$,

$>$ length: $565 \mathrm{~mm}$,

$>$ barrel length: $200 \mathrm{~mm}$,

$>$ principle of operation: gas operated - closed bolt

$>$ muzzle velocity: $830 \mathrm{~m} / \mathrm{s}$,

$>$ rate of fire: 700 rounds/min,

$>$ magazine capacity: 20,30 and 100 rounds,

$>$ effective firing range: $400 \mathrm{~m}$.

(http://www.zrno.ba/zrno/naoruzanje.html)

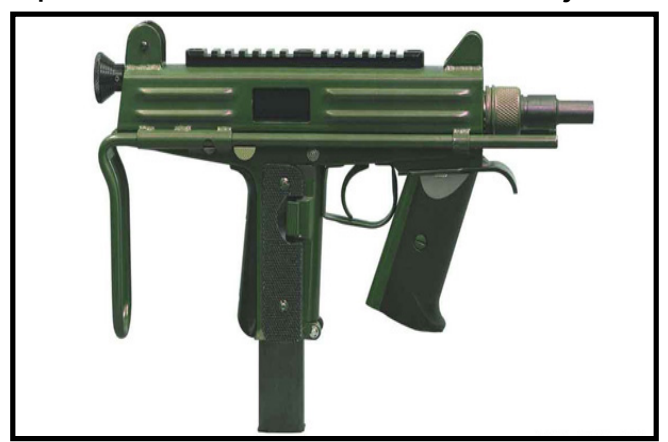

Figure 14 - CBJ MS Submachine gun

Puc. 14 - Aвтомат CBJ MS

Слика 14 - Аутомат CBJ MS

The H\&K UMP submachine gun, Figure 15, was developed as a lighter and cheaper successor to the MP5. Its production started in 1999. The working principle is free bolt recoil with a closed bolt. The submachine gun has an effective range of fire of up to $100 \mathrm{~m}$. The H\&K UMP has a folding stock that folds to the right. It uses mechanical sights 
or various optical sights on a Weaver-type rail mounted on top. There are three variants of the UMP: UMP45, using .45 ACP $(11.43 \times 23 \mathrm{~mm})$, then UMP40 with $.40 \mathrm{~S} \& \mathrm{~W}$ (10x22 mm Smith \& Wesson), and UMP9 which uses the $9 \times 19 \mathrm{~mm}$ Parabellum. In addition to a variety of ammunition, all versions have the same design, while the most striking difference is a curled magazine of the UMP9. All three versions can use any ammunition type providing the bolt, the barrel and the magazine are changed. Table 1 gives a review of the tactical and technical characteristics of the H\&K UMP submachine gun. (http://militarytoday.com)

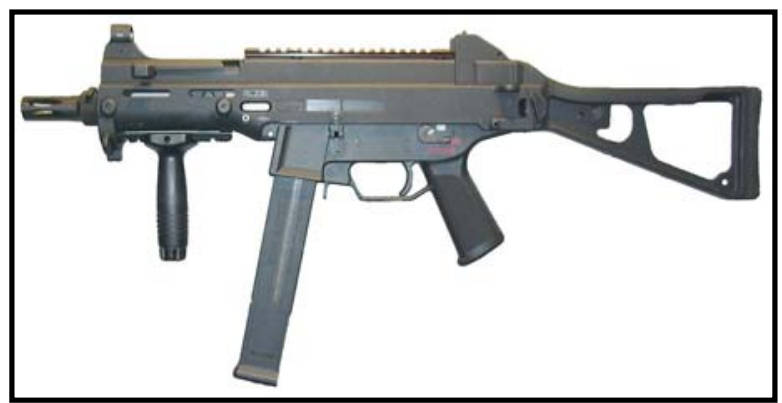

Figure $15-H \& K$ UMP Submachine gun

Puc. 15 - Автомат H\&K UMP

Слика 15 - Аутомат H\&K UMP

Table 1 - Tactical and techical characteristics of the UMP submachine gun

Таблица 1 - Тактические и технические характеристики автоматов UMP

Табела 1 - Тактичко-техничке карактеристике аутомата UMP

\begin{tabular}{|l|l|l|l|}
\hline Submachine gun model & UMP45 & UMP40 & UMP9 \\
\hline Caliber & $.45 \mathrm{ACP}$ & $.40 \mathrm{~S} \& W$ & $\begin{array}{l}9 \times 19 \mathrm{~mm} \\
\text { Para bellum }\end{array}$ \\
\hline Principle of operation & \multicolumn{3}{|l|}{ free bolt recoil - closed bolt } \\
\hline Weight in $\mathrm{kg}$ & 2.5 & 2.3 \\
\hline Length in $\mathrm{mm}$ & 690 & 200 \\
\hline Length barrel in $\mathrm{mm}$ & 285 & 650 \\
\hline Muzzle velocity in $\mathrm{m} / \mathrm{s}$ & 600 & 30 \\
\hline Rate of fire in rounds/min & 25 & \multicolumn{2}{|l|}{} \\
\hline $\begin{array}{l}\text { Magazine capacity in number } \\
\text { of rounds }\end{array}$ & 100 & \\
\hline Effective firing range in $\mathrm{m}$ & &
\end{tabular}


The H\&K MP7 submachine gun, Figure 16, is intended for combat vehicle drivers and tank and artillery crews. It represents a kind of response of Heckler \& Koch to the Belgian FN P90. The H\&K MP7 was introduced in 2000 and is currently used in the AF of Germany, South Korea and the United Kingdom. The H\&K MP7 is gas operated and uses a rotating bolt. Its internal design resembles that of the H\&K G36 automatic rifle. The H\&K MP7 submachine gun uses $4.6 \times 30 \mathrm{~mm}$ ammunition, which is also used in H\&K UCP pistols. The H\&K MP7 dimensions are those of a typical submachine gun but at close ranges it has firepower of an automatic rifle.

It was confirmed that the H\&K MP7 submachine gun penetrates the CRISAT armour at a distance of $200 \mathrm{~m}$. It is often used in offensive operations by special units. The H\&K MP7 submachine gun is well balanced and easy to handle. It can be used as a pistol, using only one hand. It also has a folding foregrip and a retractable stock. The magazine is located in the handgrip and may have a capacity of 20 or 40 rounds.

The tactical - technical characteristics:

$>$ caliber: $4.60 \times 30 \mathrm{~mm}$,

weight: $1.50 \mathrm{~kg}$,

$>$ length: $540 \mathrm{~mm}$,

$>$ barrel length: $180 \mathrm{~mm}$,

$>$ principle of operation: gas operated - rotating bolt

$>$ muzzle velocity: $725 \mathrm{~m} / \mathrm{s}$,

$>$ rate of fire: 950 rounds/min,

> magazine capacity: 20 and 40 rounds,

$>$ effective firing range: from 150 to $200 \mathrm{~m}$. (http://militarytoday.com)

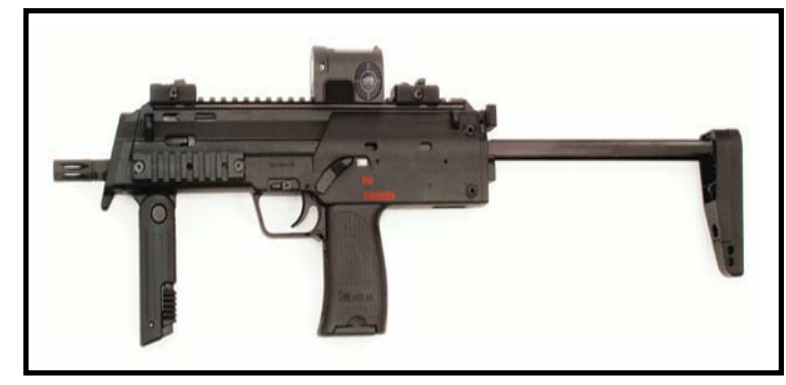

Figure 16 - H\&K MP7 Submachine gun

Puc. 16 - Автомат X\&K MP7

Слика 16 - Аутомат H\&K MP7 


\section{Conclusion}

As a type of small arms, submachine guns were widely used primarily by special units of AF for quite a number of years; however, it seemed they would forever remain in storage facilities. During the seventies of the 20th century, with the widening use of assault rifles, submachine guns were, it seemed, doomed to completely disappear from the historical scene. In fact, in most cases, it was considered that the functions of submachine guns can also be successfully performed by automatic rifles and/or assault rifles. Individuals even considered replacing submachine guns with automatic pistols with burst fire such as the Beretta 93R or the H\&K VP 70. (http://www.zrno.ba/zrno/naoruzanje.html)

However, from the nineties of the 20th century, when this type of weapons started experiencing real expansion, SMGs have secured a strong position in the time to come. This occurs mainly due to the experience of local wars around the world, large campaign wars (Gulf War), and the escalation of terrorism in the 21st century. Submachine guns stand out due to their characteristics, the following ones in particular :

$>$ possibility of higher density of fire and improved performance at the target,

$>$ low weight,

$>$ increased accuracy and precision of fire, and

$>$ ability to use a wide range of modern systems and sighting devices.

Greater attention to innovation and upgrade of the combat performances of modern submachine guns was especially paid by German (H\&K) and Israel (IMI) weapons companies. In contrast to the above countries, the United States as the leading country of NATO has only recently devoted more attention to this type of weapons, primarily due to the view of their military leadership that these weapons are considered to be supplementary weapons in many AF and police forces in the world. Proof of this lies in the fact that the United States started developing its own types of submachine guns only twenty years ago Colt SMG, SWD Ingram, KAC-9 (factory „Knight's Armament“), AP-9 and SCC-9 ( factory "Weaver Arms Corporation“) and Ruger MP9. All of the above are very compact, light and fitted with the blowback locking mechanism and a fire selector. 
Based on the foregoing, we conclude that the tendency of further development of submachine guns in the AF of the NATO countries will be focused on:

$>$ weapon weight reduction,

$>$ reducing the weapon dimensions retaining at the same time good combat performances,

$>$ increase of the magazine capacity (usually to 50 rounds), and

$>$ introduction of a new round to replace the existing $9 \times 19$ $\mathrm{mm}$ Parabellum, which will be able to penetrate modern means of personal protection.

\section{References}

Arsić, S. 1996. Savremeno naoružanje Kopnene vojske. Beograd: Novinsko-izdavačka ustanova Vojska (in Serbian).

Arsić, S. 2002a. Naoružanje Kopnene vojske. Beograd: Vojnoizdavački zavod (in Serbian).

Arsić, S. 2002b. Streljačko naoružanje sveta. Beograd: Novinsko-izdavački centar Vojska (in Serbian).

-Generalštab VJ - Uprava pešadije. 1998. Naoružanje stranih armija. Beograd: Vojnoizdavački zavod (in Serbian).

http://www.military-today.com. Accesssed: 01.02.2016.

http://world.guns.ru/smg-e.html. Accesssed: 01.02.2016.

http://www.zrno.ba/zrno/naoruzanje.html. Accesssed: 01.02.2016.

Mihajlović, M., \& Arsić, S. 2003. Specijalne snage sveta. Beograd: Novinsko-izdavački centar Vojska (in Serbian).

Petrović, M. 2009. Mehanika automatskog oružja. Beograd: Vojnoizdavački zavod (in Serbian).

Vojvodić, B. 2009. Oružje sa vizijom. Kalibar, 149, pp.11-12 (in Serbian).

АВТОМАТИЧЕСКОЕ ОРУЖИЕ В ВООРУЖЕННЫХ СИЛАХ НАТО

Ненад В. Ковачевич ${ }^{a}$, Горан М. Лазич ${ }^{б}$, Игор 3. Джорджевичв

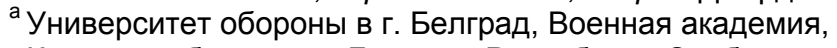

Кадетская бригада, г. Белград, Республика Сербия

б Университет обороны в г. Белград, Военная академия, Отдел вооружения и оборудования сухопутные войск, г. Белград, Республика Сербия

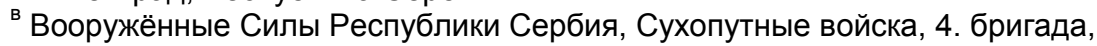
г. Вранье, Республика Сербия

РУБРИКИ: 78.25.00 Вооружение и военная техника

ВИД СТАТЬИ: профессиональная статья

ЯЗЫК СТАТЬИ: английский 


\section{Резюме:}

В данной статье представлен краткий обзор современных достижений в области развития одного из видов стрелкового оружия, а точнее автоматов, используемых зарубежными вооруженными силами, в частности в странах участницах Североатлантического Альянса (НАТО). В статье описан исторический генезис развития и использования автоматов, с акцентом на особенности данного вида огнестрельного оружия. При написании статьи авторы столкнулись с проблемой недоступности современной печатной литературы, вследствие чего обращались к интернет ресурсам. Знания об автоматах, как самого эфрорективного вида стрелкового оружия, используемых вооруженными силами зарубежных стран, могут помочь более целенаправленно рассмотреть все преимущества их применения, а также понять насколько велика потребность в инновационном подходе $и$ вложениях $в$ собственные ресурсы и средства. Статья является результатом накопленных теоретических и практических знаний авторов в области использования автоматов.

Ключевые слова: страны НАТО, вооруженные силы, автоматы.

\section{АУТОМАТИ У НАОРУЖАҢУ ОРУЖАНИХ СНАГА НАТО ЗЕМАЪА}

Ненад В. Ковачевић

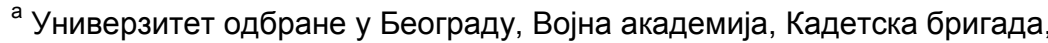

Београд, Република Србија,

${ }^{\sigma}$ Универзитет одбране у Београду, Војна академија,

Катедра наоружања и опреме КоB-а, Београд, Република Србија,

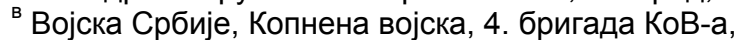

Врање, Република Србија

ОБЛАСТ: наоружање

ВРСТА ЧЛАНКА: стручни рад

ЈЕЗИК ЧЛАНКА: енгЛески

\section{Сажетак:}

Чланак представља кратак преглед модерних достигнућа и правце даљег развоја једне врсте стрељачког наоружања аутомата у оружаним снагама земаља потписницама Северноатлантског савеза (НАТО). Прати и развој употребе аутомата, као посебне врсте стрељачког наоружања. У недостатку новије литературе у раду су умногоме коришћени подаци са интернета. Познавањем аутомата, као једне од најефекасније и најефективније врсте стрељачког наоружања страних оружаних снага могу се на сврсисходнији начин сагледати њихови ефекти употребе, као и потреба за иновацијама и 
улагањем у сопствене ресурсе. Чланак представља сублимат искустава из праксе и теоретских сазнања аутора у вези са употребом аутомата.

Кључне речи: НАТО земље, оружане снаге, аутомати.

Paper received on / Дата получения работы / Датум пријема чланка: 10.02.2016. Manuscript corrections submitted on / Дата получения исправленной версии работы / Датум достављања исправки рукописа: 10.01.2019.

Paper accepted for publishing on / Дата окончательного согласования работы / Датум коначног прихватања чланка за објављивање: 12.01.2019.

(c) 2019 The Authors. Published by Vojnotehnički glasnik / Military Technical Courier (www.vtg.mod.gov.rs, втг.мо.упр.срб). This article is an open access article distributed under the terms and conditions of the Creative Commons Attribution license (http://creativecommons.org/licenses/by/3.0/rs/)

() 2019 Авторы. Опубликовано в «Военно-технический вестник / Vojnotehnički glasnik / Military Technical Courier» (www.vtg.mod.gov.rs, втг.мо.упр.срб). Данная статья в открытом доступе и распространяется в соответствии с лицензией «Creative Commons» (http://creativecommons.org/licenses/by/3.0/rs/)

(c) 2019 Аутори. Објавио Војнотехнички гласник / Vojnotehnički glasnik / Military Technical Courier (www.vtg.mod.gov.rs, втг.мо.упр.срб). Ово је чланак отвореног приступа и дистрибуира се у складу са Creative Commons лиценцом (http://creativecommons.org/licenses/by/3.0/rs/).

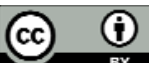

